\title{
Re-imagining Metro Manila: Potential Impacts of Mass Transit for a Megalopolis
}

\author{
Dominic S. Aloc ${ }^{1 *}$, Jose Regin F. Regidor ${ }^{2}$ \\ ${ }^{1}$ College of Engineering, University of the Philippines, Diliman, Quezon City, Philippines \\ ${ }^{2}$ Institute of Civil Engineering, University of the Philippines, Diliman, Quezon City, Philippines \\ *Corresponding author:dsaloc@up.edu.ph
}

\begin{abstract}
Metro Manila is a metropolis comprised of 15 cities and 1 municipality with a population of over 13 million people. It is already considered as a megalopolis together with adjoining provinces to the north, east and south. Despite it being highly urbanized, the city is dependent of road-based transport, with about $80 \%$ of commuters taking public transportation but with $70 \%$ of road space taken up by cars. Metro Manila currently has only 4 railways lines - Line 1 along Taft Avenue, Rizal Avenue and EDSA, Line 2 along Aurora Boulevard and Marcos Highway, Line 3 along EDSA, and the commuter line of the old Philippine National Railways. If plans formulated since the 1970s were realized, then commuting would have been very different in Metro Manila, where majority of commuters could have been using rail-based transport. This study examines the counterfactual scenarios of mass transit development in the context of co-benefits for Metro Manila over the past four decades, focusing on rail transport. The outcomes of simulated scenarios are used as inputs towards the quantification of transport co-benefits. These co-benefits include improved air quality, more efficient fuel consumption, safer roads, and reduced travel time. The evaluation procedure was based from the Transport Co-benefits Guidelines developed by the Institute of Global Environmental Strategies. The assessment of transport and traffic conditions as related to rail-based mass transit development showed a very significant potential for alleviating transport and traffic congestion in Metro Manila, thereby improving the quality of life for people.
\end{abstract}

Keywords—mass transit; co-benefits; rail transport

\section{INTRODUCTION}

$\mathrm{E}$ arlier development seemed to centerpiece its objectives by addressing the social and economic aspects of a region. But in the recent years, gradual change in the Earth's climate, alongside with rapid growth of population and its mobility, have redirected the focus to integrating sustainable measures as another development criterion. One active movement to achieve this is the formation of the United Nations Framework Convention on Climate Change (UNFCCC) in 1992, which has been the cornerstone of various jurisdictions in gearing towards fighting the adverse effects of climate change. The Convention acknowledges that human activities can lead to an increase in atmospheric concentration of greenhouse gases, and thus calls for the international cooperation of each country to enact laws to address this environmental degradation. As the leading pact that pushes for climate change mitigation globally, the UNFCCC has the ultimate objective of stabilizing the "greenhouse gas concentrations at a level that would prevent dangerous anthropogenic interference with the climate system" [1]. Several Parties participated in by signing into the agreement, and started their commitment since to the principles stated in Article 2 of the Convention.

In December 1997, a recall to the provisions of the Convention was held in Kyoto, Japan which was referred to as the Kyoto Protocol. The agreement established quantified emission limitation and reduction commitments per Party with a major aim of reducing the greenhouse gas concentration below 5\% below their 1990 levels in the 4-year commitment period from 20082012 [2]. Since then, several regional economic integration organizations, government agencies, private organizations, etc. have already taken steps that would encourage initiatives concerning climate change mitigation. The latest transaction to the Convention is the Paris Agreement in 2015 that reiterated its implementation and aimed to "strengthen the global response to the threat of climate change" [3].

A renewed interest linked to the UNFCCC mission is the integration of co-benefits approach in policymaking processes as it guides not only the development but also evaluates the environmental benefits that can be derived from implementing a particular project or policy. Methodologies to quantify such benefits have already been studied such as the tool developed by the Institute of Global Environmental Strategies (IGES). In this research, the past rail transport plans are studied as a basis of reducing the effects of climate change. The potential impacts are the co-benefits that would touch on the reduction of $\mathrm{CO}_{2}$ and other air pollutants as well as other transport-related benefits, and are quantified using the developed tool by IGES. The idea being theorized is that, given these rail projects had been implemented, Metropolitan Manila could have been well-planned that could have dealt not only with the social and economic aspects but also could have touched on the environmental benefits by constructing such plans. 


\section{A. Objectives}

This study examines the counterfactual of mass transit development scenarios in the context of co-benefits for Metropolitan Manila (currently recognized as Metro Manila) over the past four decades, focusing on rail transport. Specifically, this research aims to discuss the co-benefits application on transport, and to quantify the co-benefits from the past transport projects identified that had been subjected for Metro Manila. The cobenefits under consideration are travel time savings, vehicle operating cost savings, traffic safety benefits, and environmental benefits. The quantitative procedure adopted was based from the Transport Co-benefits Guidelines (TCG) developed by the Institute of Global Environmental Strategiees (IGES).

\section{CO-BENEFITS APPROACH}

Since the Kyoto Protocol in 1997, several countries have been in synergy to address the impact of climate change, and in constant mission to reduce greenhouse gas (GHG) emissions. From there on, integration of climate change countermeasures has been introduced in policymaking processes, and co-benefits approach (also known as co-benefits strategy or co-controls or cocontrol measures) is one way to perform it.

In Japan, the Ministry of the Environment, being one of the pioneering agencies that made a move to achieve this mission, has been supporting initiatives that exercise co-benefits approach since 2006. The Ministry labelled it as co-benefits approach to climate change countermeasures, and further defined it as a new projectbased approach that aims to improve the local environment while addressing climate change concerns. This action touched on three (3) areas of interest which are: air quality improvement, water quality improvement and waste management. Air quality issue deals with the improvement in combustion efficiency at factories and power plants, and the realization of environmentally sustainable transport systems. Meanwhile, the use of methane recovered from the wastewater discharged from factories and business offices encompassed the water quality issue. Lastly, waste management tackles on the use of urban waste as compost, and conversion of landfill structures to aerobic or semi-aerobic systems [4].

Concurrently, the United States Environmental Protection Agency's (US EPA) Integrated Environmental Strategies (IES) program defines cobenefits as the benefits derived together from a single measure or set of measures. It is also the health and economic benefits from the reduction of air pollutants, and GHG reductions associated with reducing ambient emissions. An IES Handbook was developed in 2004 to quantify the co-benefits that can be derived from implementing policy, technology and infrastructure. The Handbook further describes the processes in selecting the base-year emissions inventory of air pollutants and emissions to be included in the analysis, estimating the avoided mortality and morbidity incidences and their corresponding monetary values [5].
The other relevant agencies and organizations that have been involved with the issues of co-benefits are Intergovernmental Panel of Climate Change (IPCC), Institute of Global Environmental Strategies (IGES), Clean Air Initiative for Asian Cities (CAI-Asia), and European Environment Agency (EEA). Each of the aforementioned unit has defined co-benefits, and Table 1 summarizes it.

\section{A. Co-benefits in Transport}

The transport sector registers the road transport as a dominant producer of greenhouse gas emissions [6]. Since fossil fuel is needed to power motorized vehicles, a rapid growth of motorized vehicles leads to increased fossil fuel consumption. These vehicles, in turn, emit carbon dioxide that contributes to greenhouse gases present in the atmosphere. This growing number of motorized vehicles and its corresponding fuel consumption and emissions pose as a challenge that is seemingly reducible through co-benefits approach. A window of opportunity appears in the integration of cobenefits approach in the transport planning process as it does not only maximize the benefits but also minimize the long-term costs [6].

Several related organizations have already developed tools to easily evaluate projects that make use of cobenefits approach. IGES is one of the organizations that have been conducting studies related to co-benefits application in transport. The TCG developed by IGES is holistic in nature as it computes not only the emissions costs, but also other transport-related costs such as travel time costs, vehicle operating costs, and accident costs. Given the baseline scenario and the design year, the benefits can be readily computed as the difference of the two cases. The TCG tool requires some data inputs such as the number of vehicle, type of vehicle, traffic volume, number of lanes in the road, among others [7]. It must be noted that this evaluation technique has been adopted for the methodology of this research.

Meanwhile, in 2014, the United Nations University Institute of Advanced Studies (UNU-IAS) published a guidebook that can evaluate the magnitude of the emission reductions from local air pollution and carbon emissions, and can determine barriers for the implementation of urban transport projects. This guidebook directs to a tool that is composed of two elements: a) institutional or governance dimension; and b) technical analysis. The tool would simply ask for inputs such as the number of vehicles, utilization rate, average travel distance, average occupancy (load factor), fuel efficiency, and a supplementary input parameter, modal share, would then be computed from the previous datasets. The resulting figures would be the GHG emissions and other air pollutions per vehicle type. [8].

A prototype co-benefits calculator was released by professors in Australia in 2016 that made use of effects on the interaction of land use characteristics and transport choice and health. The model included the variables distance, density, diversity, design, and transport mode choice. 


\section{B. Co-benefits Approach in Philippine Transport}

The Philippines adopted the IES program of US EPA. Air Pollution Health Benefits Analysis (APHEBA) model was introduced by IES team from Chile as part of the IES program that can calculate the benefits upon reducing the air pollution concentrations for a given location and time period. A couple of policymakers training agenda followed in 2003 with the attendance of the Department of Environment and Natural Resources, Department of Transportation and Communications, Department of Energy, League of Cities/Municipalities and the Interagency Committee on Environmental Health. The discussions touched on scenario development, modeling, health effects analysis, and economic analysis. This series of trainings had been expected to help in guiding the integration of the analysis models and tools into the country's policymaking processes [5].

The awareness about co-benefits was put to spotlight when the Manila Observatory (MO) together with Clean Air Initiative for Asian Cities (CAI-Asia) introduced this approach through the Co-benefits of Climate Change Mitigation: Coordinator in Asia Project. Funded by US EPA, the project was implemented from October 2006 to June 2007 and was aimed at consolidating and disseminating information about co-benefits initiatives in Asia through literature review and analysis [9].

In 2011, a case study calculating the co-benefits from the proposed Bus Rapid Transit along the Circumferential Road 5 (C-5) corridor was completed. The study used the TCG developed by IGES that provided the values of travel time savings, vehicle operating cost savings, traffic safety benefits, and environmental benefits [6]. The same methodology was used in 2015 by Fillone [10] that compared the baseline scenario in 2014 (i.e., without the new projects) to the design years 2020 and 2030 when the new expressways and mass transit systems would then be built. Eleven (11) scenarios were modeled in which scenario 1 being the baseline case.

\section{METHODOLOGY}

A brief description of the area under consideration is discussed in this section as well as the methodology used that was based from Transport Co-benefits Guidelines (TCG) of the Institute of Global Environmental Strategies (IGES).

\section{A. Study Area}

Metro Manila (Figure 1) is a metropolis comprised of 15 cities and 1 municipality with a population of over 13 million people. It is already considered as a megalopolis together with adjoining provinces to the north, east and south. Despite it being highly urbanized, the city is dependent on road-based transport, with about $80 \%$ of commuters taking public transportation but with $70 \%$ of road space taken up by cars. Metro Manila currently has only 4 railways lines - Line 1 along Taft Avenue, Rizal Avenue and EDSA, Line 2 along Aurora Boulevard and Marcos Highway, Line 3 along EDSA, and the commuter line of the old Philippine National Railways (PNR).

\section{B. Method Used}

This section details the evaluation procedure that was based from the TCG developed by IGES. The TCG, as it has been described, focuses on transport projects, and the devised tool can be used to clarify the steps in estimating the reductions of $\mathrm{CO}_{2}$ and other air pollutants along with travel time savings, vehicle operating cost savings and accident cost savings from these projects. It is important to note, however, that TCG derived its method from the Japan Research Institute's (JRI) "Guidelines for the Evaluation of Road Investment Projects." [6]

Meanwhile, before the estimation of co-benefits, the traffic demand forecasts are needed. This forecasting models would enable the authors to compare and contrast the "with" and "without project" scenarios. The "with project" pertains to the state at which the rail transit plan is implemented. On the other hand, the "without project" is the no intervention state of the area being studied. Regidor et al. [11] have already generated transport models corresponding to each rail transport plan discussed below. The results are tabulated in Table 2 . For easier computation, only the co-benefits of the pessimistic case have been computed since this would be the design scenario - that is, if only $5 \%$ private users shifted to public transport due to the construction of the rail facility.

The four (4) co-benefits listed down in TCG are travel time savings, vehicle operating cost savings, traffic safety benefits, and environmental benefits. Each of them is discussed below.

One of the largest costs in transport is travel time [12]. The more is the time one spends in traveling, the higher is the value of travel time cost. Normally, the cost of travel time is derived by the product of the travel time and the value of time. Studies related to travel time cost suggest that the value of travel time depends on the mode of transport and its level of service [12]. Meanwhile, IGES [6] provided a formula to calculate the total cost of travel for a year which is:

$B T_{i}=\sum_{j} \sum_{l}\left(Q_{i j l} \times T_{i j l} \times \alpha_{j}\right) \times 365$

where $i$ can be any variable that can represent the "with" and "without project (or policy)" scenarios, $B T_{i}$ is the total cost of travel per year, $Q_{i j l}=$ traffic volume for $j$ vehicle type on link $l$ (vehicle/day), $T_{i j l}$ is the average travel time for $j$ vehicle type on link $l$ (minutes), and $\alpha_{j}$ is the value of time for $j$ vehicle type (monetary unit/minute $\mathrm{x}$ vehicle). The value of travel time savings can be derived by subtracting the total cost of travel per year "with project" from the total cost of travel per year "without project."

Unlike in travel time cost, vehicle operating cost (VOC) is distance-based. The more the vehicles travel, the higher is the value of VOC. VOC encompasses the cost of fuel, oil, tire and tube, maintenance and depreciation of the vehicle. Unit VOC is dependent mainly on the road type and the driving conditions, travel speed, and other factors [6]. 
The formula used by IGES [6] to compute for the total vehicle operating cost per year is:

$$
B R_{i}=\sum_{j} \sum_{l}\left(Q_{i j l} \times L_{l} \times \beta_{j}\right) \times 365
$$

where $i$ can be any variable that can represent the "with" and "without project" scenarios, $B R_{i}$ is the total VOC per year, $Q_{i j l}=$ traffic volume for $j$ vehicle type on link $l$ (vehicle/day), $L_{l}$ is the link length of link $l(\mathrm{~km})$, and $\beta_{j}$ is the value of VOC for $j$ vehicle type (monetary unit $/ \mathrm{km}$ $\mathrm{x}$ vehicle). The value of vehicle operating cost savings can be derived by subtracting the total VOC per year "with project" from the total cost of travel per year "without project."

The benefits in traffic safety lies on the decrease of crash or accident occurrences once the project is implemented. IGES [6] makes use of a formula that computes the accident losses for the "with" and "without project" scenarios. The equation is link-based and intersection-based. But due to the intricacies of the formula and the absence of necessary data on the intersections, the authors used the link-based approach by Miller [13]. Given the vehicle-distance-traveled (VDT) in vehicle-kilometer estimated by Regidor et al. [11], the total cost of damages can be computed by multiplying the unit cost per mode specified by Miller [13] and VDT. The value of traffic safety benefits can be derived by subtracting the total cost of damages per year "with project" from the total cost of damages per year "without project."

Environmental benefit is contextualized as the savings derived from the reduction of greenhouse gas emissions and other air pollutants. Just like in VOC, environmental cost depends on the mode of transport and the level of service it gives, particularly the speed.

IGES [6] recommended a bottom up approach to estimate greenhouse gas emissions and other air pollutants. This can be done by first estimating the emissions per pollutant, and thereafter, calculating the damage costs based from the estimated emissions. The formula for calculating the emissions are:

$$
\begin{aligned}
& B E_{i, k}=\sum\left(Q_{B L, j, k} \times L_{k} \times E F_{i, j, V_{B L}, k}\right) \\
& P E_{i, k}=\sum\left(Q_{P J, j, k} \times L_{k} \times E F_{i, j, V_{P J}, k}\right)
\end{aligned}
$$

where $B E_{i, k}$ is the baseline emission of pollutant $i$ at link $k$ (kg/day), $Q_{B L, j, k}$ is the baseline daily traffic volume of vehicle type $j$ at link $k$ (unit/day), $L_{k}$ is the link length of link $k(\mathrm{~km}), E F_{i, j, V_{B L}, k}$ is the baseline emission factor of pollutant $i$, vehicle type $j$ at average speed $v_{B L, k}$ (kg/km/unit), $P E_{i, k}$ is the project emission of pollutant $i$ at link $k(\mathrm{~kg} / \mathrm{day}), Q_{P J, j, k}$ is the project daily traffic volume of vehicle type $j$ at link $k$ (unit/day), and $E F_{i, j, V_{P J}, k}$ is the project emission factor of pollutant $i$, vehicle type $j$ at average speed $v_{B L, k}(\mathrm{~kg} / \mathrm{km} / \mathrm{unit})$. The baseline case is the "without project" scenario while the project case is the "with project" scenario.

On the other hand, the calculation of damage costs is employed by multiplying the unit cost value of each pollutant and the amount of emissions obtained from the emission estimation above. The value of environmental benefits is derived by subtracting the sum of the total damage cost of all pollutants per year "with project" from the sum of the total damage cost of all pollutants per year "without project."

\section{TRANSPORT PLANS FOR METRO MANILA}

In this section, the past rail transit plans identified to where the co-benefits were derived from are discussed. These rail transit plans are Urban Transport Study in Manila Metropolitan Area (UTSMMA), Metro Manila Transport, Land Use and Development Planning Project (MMETROPLAN), and Metro Manila Urban Transportation Integration Study (MMUTIS). As the plans that had been recognized and supported by the Philippine government at the time, these studies now appear to be as missed opportunities since most, if not all, of the plans' recommendations were not implemented.

\section{A. UTSMMA}

Completed in 1973 by a pool of Japanese transport experts of Overseas Technical Cooperation Agency (OTCA), this transport plan was actually a product of the Philippine Government's request from the Japan Government for technical assistance to alleviate the transport problems experienced in Metropolitan Manila. The plan eventually recommended a heavy rail transit network composed of five lines and the improvement of the Philippine National Railways [14]. Each subway line is described in Table 3 and is mapped out in Figure 2.

\section{B. MMETROPLAN}

MMETROPLAN recognized the existence of UTSMMA, and suggested a light rail transit network, contradictory to what UTSMMA had recommended. Completed in 1977, the London-based consultancy firm Freeman Fox and Associates was commissioned by the Philippine Government to carry out this study. During the planning stage, it made use of the survey results of UTSMMA as instructed in the terms of reference, and came up with 5 routes that were mostly elevated. The current Light Rail Transit Line No. 1 (LRT-1) of Metro Manila was actually based from the alignment of the Rizal-Taft route of MMETROPLAN [15]. However, the change of government and the lack of financing halted the completion of the remaining light rail transit lines. Table 4 and its map in Figure 3 show the routes suggested by MMETROPLAN.

\section{MMUTIS}

Japan International Cooperation Agency (JICA), formerly known as OTCA, carried out this study that was completed in 1999. The plan's aims were to establish an updated transportation database for Metro Manila, and to formulate a medium-term Transport Development Plan for 1999-2004, and a master plan intended to be completed in the year 2015 [16].

LRT-1 was already fully operational upon the completion of this study. While the current Light Rail Transit Line No. 2 (LRT-2) and Metro Rail Transit Line 
No.3 (MRT-3) had been underway in its construction, several extensions had already been proposed through this study. Up until today, the extensions of the lines and other recommendations have not been implemented. Table 5 shows the descriptions of these lines which are represented by the lines in Figure 4.

\section{RESULTS AND DISCUSSION}

The values of the travel demand forecasts by Regidor et al. [11] were used mainly for the quantification of the co-benefits identified. It is also important to note that the output of the forecasting process predicted the 2014 scenario. The results of the model have the attributes and the corresponding description shown in Table 6.

\section{A. Travel Time Savings}

The unit values of time for private and public vehicles were decided based upon the values of JICA [17] and the interpolated values from MMUTIS [16]. JICA used 1.86 $\mathrm{PHP} / \mathrm{min}$ for the private cars while $1.30 \mathrm{PHP} / \mathrm{min}$ is for the jeepneys and buses. For MMUTIS, the values of 101.20 PHP/min and 123.50 PHP/min were designated for 2010 and 2015, respectively, for private mode while 81.6 PHP/min and 99.6 PHP/min for the same period for public mode. Since MMUTIS was clearer in pointing out the public mode as compared to the modes of jeepneys and buses described by JICA, the MMUTIS was taken as the basis for the value of time. The resulting interpolated values of travel time are $96 \mathrm{PHP} / \mathrm{min}$ and 119.04 $\mathrm{PHP} / \mathrm{min}$ for public and private modes, respectively.

Given the volume of the private and public vehicles, and the time it takes for the vehicles to pass a given link as outputs of the forecasting process, the total travel time cost can be computed using equation (1). The summary of the total travel time costs and savings per project is shown in Table 7.

To examine the resulting trend, vehicle-hour-traveled (VHT) is the parameter that gives the estimates of how much time the vehicles would travel. Table 2 shows that at the same level of modal shift from private vehicles to public transport (i.e., pessimistic scenario of 5\% shift), it can be seen that the vehicles would reduce the travel time most in MMUTIS, followed by MMETROPLAN, and lastly, in UTSMMA. This observation just matches the co-benefits derived in terms of the travel time cost savings shown in Table 7 as MMUTIS accrued the highest value of savings.

\section{B. Vehicle Operating Cost Savings}

Vehicle operating cost was computed using equation (2). From the specified value of unit VOC (i.e., 7.30 $\mathrm{PHP} / \mathrm{km}$ ) by JICA [17], and from the volume of the private and public vehicles, and the length of the links as outputs of the forecasting process, the total VOC savings have been calculated. The summary of the total VOC savings per project is shown in Table 8 .

Looking at the pessimistic scenarios in Table 2, it can be observed that UTSMMA incurred the highest value of vehicle-distance-traveled (VDT), followed by MMETROPLAN, and then MMUTIS. VDT describes how farther the vehicles would travel at a given scenario.
Since the vehicles in UTSMMA traveled the most, this can be translated to more fuel and cost of maintenance, among others, are expected and thus having the least value in vehicle operating cost savings (Table 8). This, in turn, made MMUTIS as the one with the highest value of savings.

\section{Traffic Safety Benefits}

For traffic safety benefits as well as the environmental benefits, only the values for the private mode were computed due to lack of necessary data that would have characterized the volume per mode of public transport.

The link-based approach by Miller [13] that specified the unit value of damage cost per mode was used. Given the volume of private vehicles and the length of the links, VDT can be computed and the resulting damage costs and benefits are shown in Table 9.

Since the values used by Miller is in USD, it can be observed from Table 9 that the initial computation was in USD. The authors made use of an open source site (i.e., www.oanda.com) that converts exchange rates on a historical approach. From that site, the value of USD in 1994 to PHP in 2014 was estimated and was used for the benefit computation.

Since the formula used was link-based, it followed the trend as computed in the vehicle operating cost savings. The transport plan with the highest traffic safety benefits would be the one with the least value of VHT - thus, MMUTIS (Table 9). This means that the more vehicles traveled in greater distances, the more damage cost or accident cost would be incurred.

\section{Environmental Benefits}

The emissions were computed using equation (3) for the "without project" scenario and equation (4) for the "with project" scenarios. Given the volume of the private vehicles, the lengths of the link as outputs of the forecasting process, and the emission factors per pollutant specified by IGES [6] that are speed-dependent, the total amount of emissions for each pollutant can be computed from the aforementioned equations. The summary of the total amount of emissions per project is shown in Table 10. To convert the emissions into damage costs, the unit cost of each pollutant must be obtained. Toshiyumi et al. [18] studied for the unit cost of $\mathrm{SO}_{\mathrm{x}}$ in USD while European Commission [19] had the values for $\mathrm{CO}$ and $\mathrm{CO}_{2}$ unit costs in EUR. Table 11 shows the damage cost of private vehicles per transport plan in foreign currencies while Table 12 displays the overall-environmental benefits. It can be observed that MMUTIS could have made an PHP 8.88 Billion / year of savings, had it been implemented, the highest value among the three (3) transport plans.

\section{CONCLUSION}

Using the TCG introduced by IGES, the co-benefits have been estimated from the past rail transit plans namely, UTSMMA, MMETROPLAN, and MMUTIS for the year 2014. Travel time savings, vehicle operating cost savings, traffic safety benefits, and environmental 
The Third International Conference on Civil Engineering Research (ICCER)

August $1^{\text {st }}-2^{\text {nd }}$ 2017, Surabaya - Indonesia

benefits (i.e., $\mathrm{NO}_{\mathrm{x}}, \mathrm{CO}$, and $\mathrm{CO}_{2}$ cost savings) were the co-benefits that have been tackled by the method.

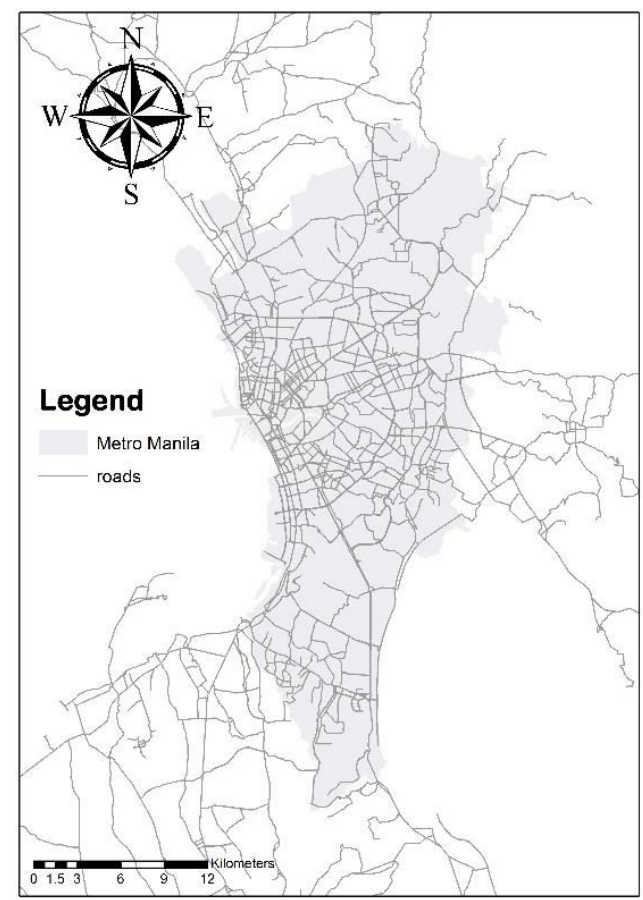

Figure 1. Map of Metro Manila.

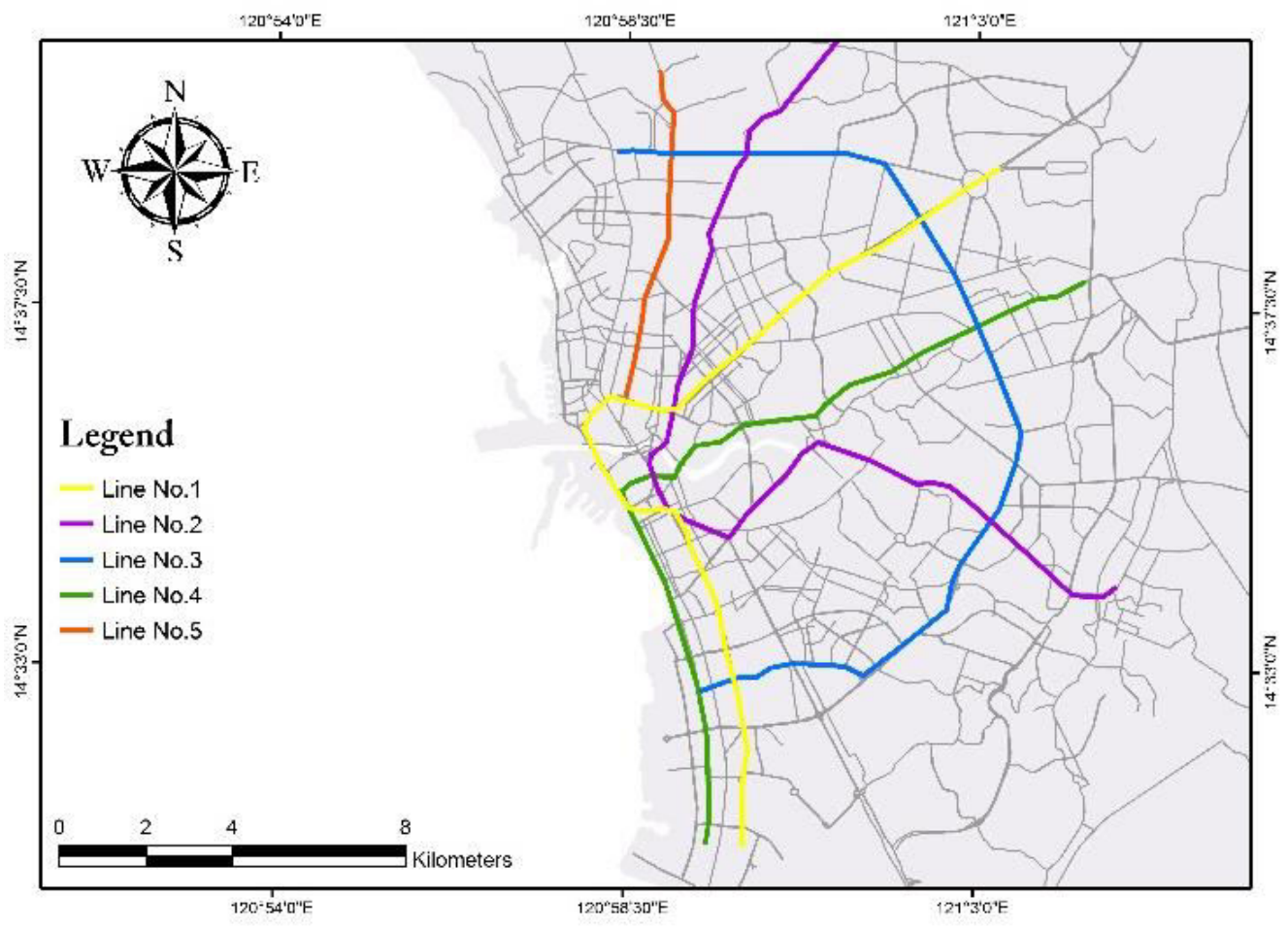

Figure 2. Lines of UTSMMA. 


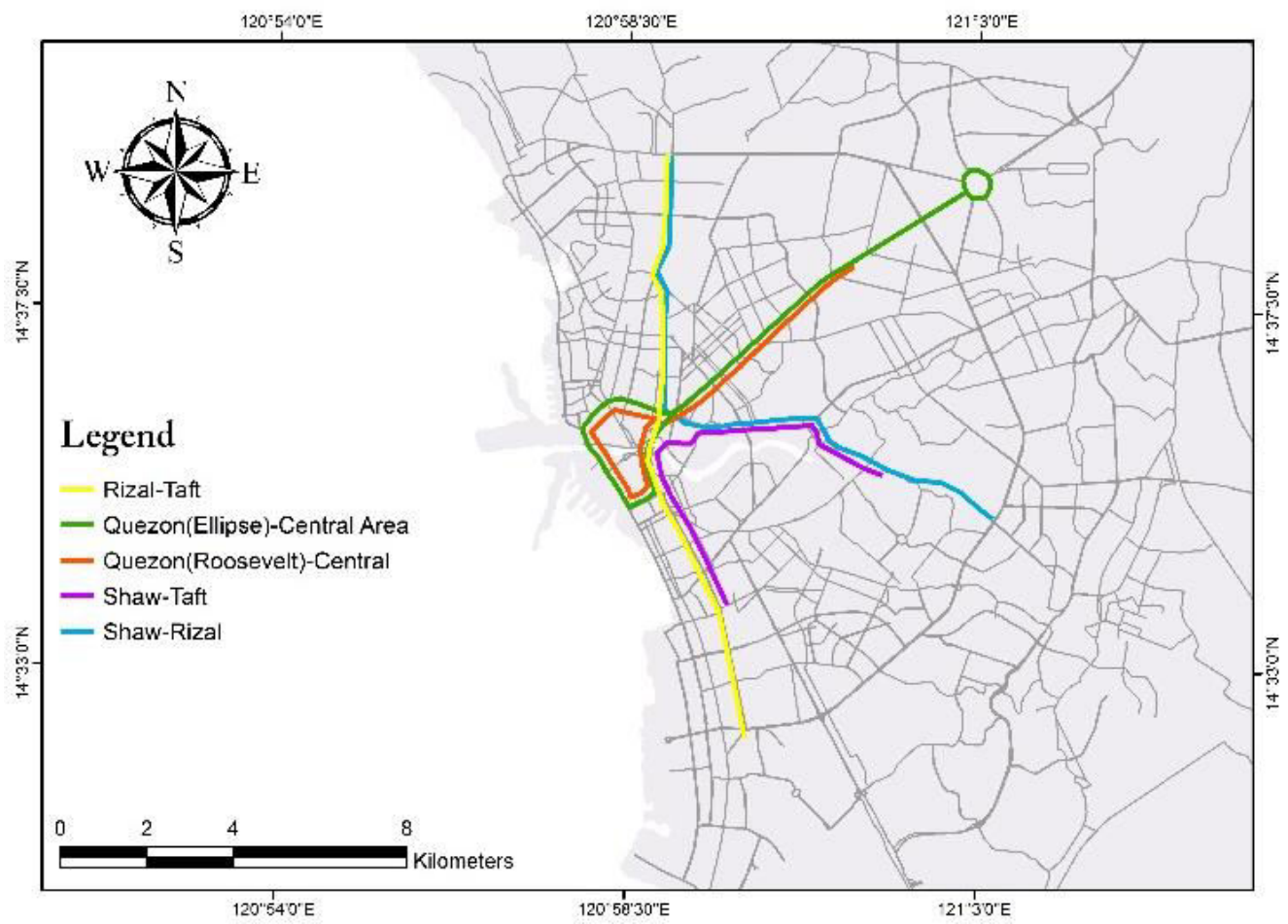

Figure 3. Lines of MMETROPLAN.

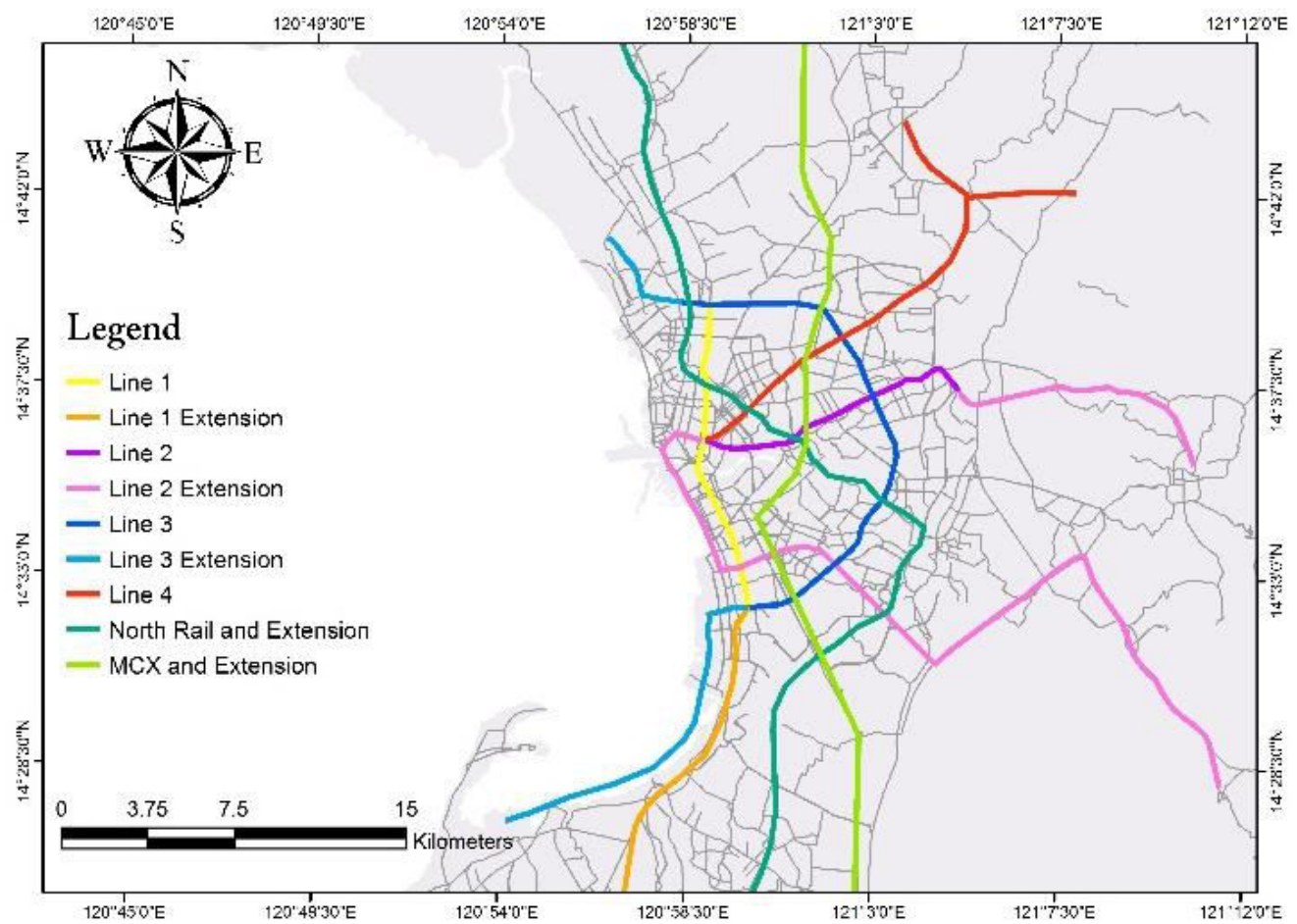

Figure 4. Lines of MMUTIS. 


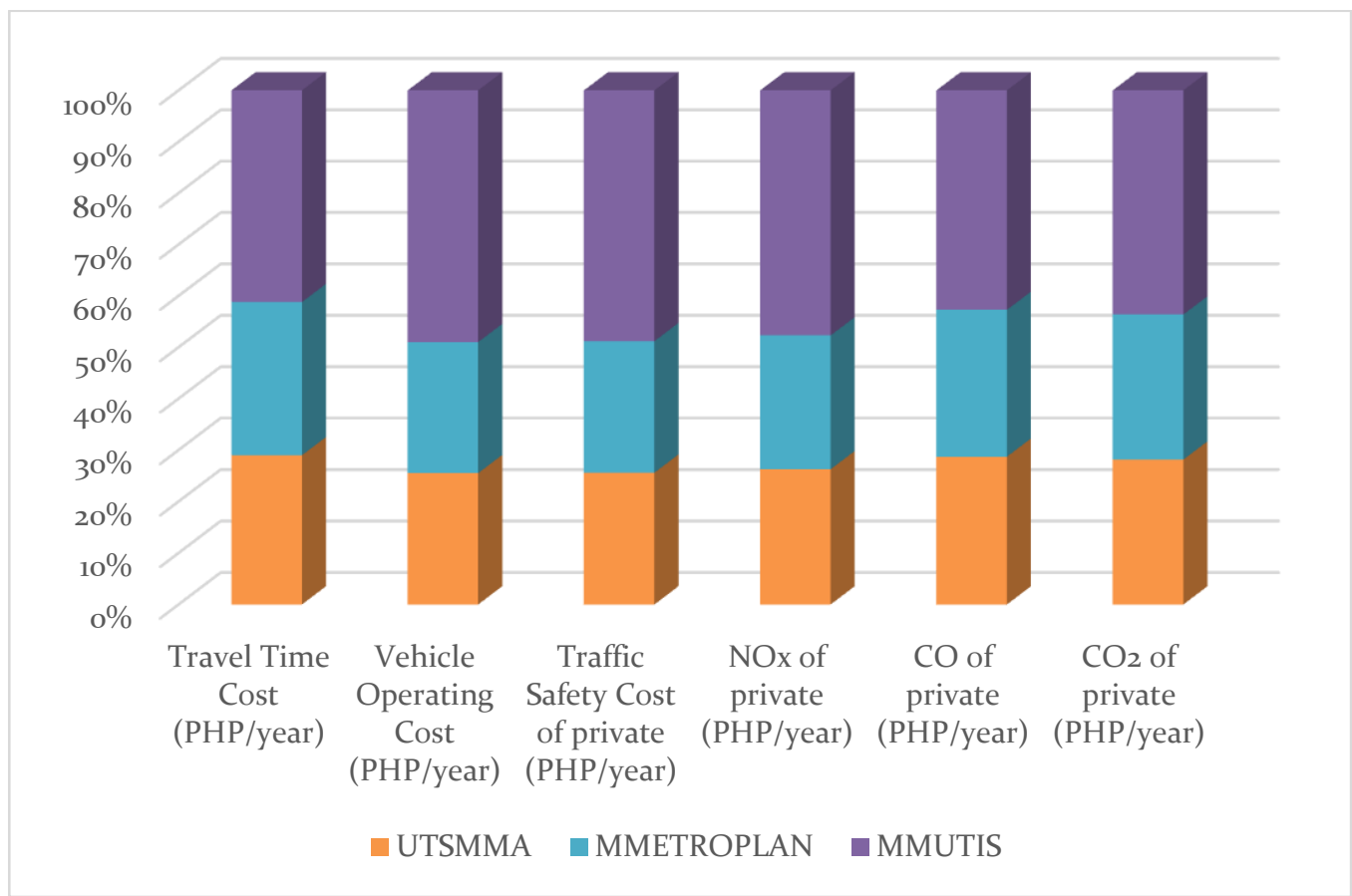

Figure 5. Percentage of co-benefits derived per transport plan.

Table 1. Other definitions of co-benefits [9]

\begin{tabular}{|c|l|}
\hline Unit & \multicolumn{1}{c|}{ Definition of Co-benefits } \\
\hline IPCC & $\begin{array}{l}\text { Benefits intended as the primary objective of certain actions or policies from } \\
\text { those that are secondary or incidental to it are named simply as "ancillary } \\
\text { benefits." }\end{array}$ \\
\hline IGES & $\begin{array}{l}\text { Potential benefits of climate change mitigation actions in other field or areas not } \\
\text { covered by climate change or United Nations Framework Convention on Climate } \\
\text { Change (UNFCCC). }\end{array}$ \\
\hline CAI-Asia & $\begin{array}{l}\text { Those derived from the intentional decision to address air pollution, energy } \\
\text { demand, and climate change in an integrated manner, but also considers the other } \\
\text { unspecified benefits that may arise such as improved transport and urban } \\
\text { planning, reduced health and agricultural impacts, improved economy or reduced } \\
\text { overall policy implementation cost. }\end{array}$ \\
\hline EEA & $\begin{array}{l}\text { The efficient use of resources of co-control strategies particularly for air pollution } \\
\text { and climate change. }\end{array}$ \\
\hline
\end{tabular}

Table 2. Modeling results of EMME4, Peak Hour Trips [11]

\begin{tabular}{|c|r|r|r|r|r|r|r|}
\hline \multirow{2}{*}{ Parameters } & \multirow{2}{*}{ Baseline } & \multicolumn{2}{|c|}{ UTSMMA } & \multicolumn{2}{c|}{ MMETROPLAN } & \multicolumn{2}{|c|}{ MMUTIS } \\
\cline { 3 - 8 } & $\begin{array}{c}\text { Pessimistic } \\
\mathbf{5 \%} \text { shift }\end{array}$ & $\begin{array}{c}\text { Optimistic } \\
\mathbf{2 0 \%} \text { shift }\end{array}$ & $\begin{array}{c}\text { Pessimistic } \\
\mathbf{5 \%} \text { shift }\end{array}$ & $\begin{array}{c}\text { Optimistic } \\
\text { 20\% shift }\end{array}$ & $\begin{array}{c}\text { Pessimistic } \\
\mathbf{5 \%} \text { shift }\end{array}$ & $\begin{array}{c}\text { Optimistic } \\
\mathbf{2 0 \%} \text { shift }\end{array}$ \\
\hline $\begin{array}{c}\text { Private Trips } \\
\text { (OD) }\end{array}$ & $1,077,680$ & $1,022,900$ & 861,562 & $1,022,900$ & 861,562 & $1,022,900$ & 861,562 \\
\hline $\begin{array}{c}\text { Public Transit } \\
\text { Trips (OD) }\end{array}$ & $2,700,570$ & $2,755,340$ & $2,916,680$ & $2,755,340$ & $2,916,680$ & $2,755,340$ & $2,916,680$ \\
\hline $\begin{array}{c}\text { Average travel } \\
\text { speed, kph }\end{array}$ & 13.97 & 15.67 & 18.58 & 15.59 & 18.59 & 15.92 & 18.85 \\
\hline VCR & 1.365 & 0.793 & 0.666 & 1.021 & 0.665 & 0.758 & 0.637 \\
\hline VHT (veh-hr) & $4,667,566$ & $2,893,236$ & $1,275,911$ & $2,841,470$ & $1,254,075$ & $2,502,129$ & $1,111,829$ \\
\hline VDT (veh-km) & $11,084,477$ & $10,586,890$ & $8,623,877$ & $10,586,740$ & $8,617,979$ & $10,281,763$ & $8,406,410$ \\
\hline $\begin{array}{c}\text { Passenger-km } \\
\text { (All Transit) }\end{array}$ & $33,222,324.2$ & $35,016,608$ & $37,836,692$ & $30,583,217.5$ & $37,384,306.3$ & $34,229,653$ & $36,094,176$ \\
\hline
\end{tabular}




\begin{tabular}{|c|c|l|}
\hline Line & $\begin{array}{c}\text { Length } \\
(\mathbf{k m})\end{array}$ & \multicolumn{1}{|c|}{ Description } \\
\hline No.1 & 27.1 & $\begin{array}{l}\text { From Construction Hill to Talon via central Quezon } \\
\text { Boulevard, Manila downtown and the International } \\
\text { Airport. }\end{array}$ \\
\hline No.2 & 36.0 & $\begin{array}{l}\text { From Novaliches to Cainta via Manila downtown } \\
\text { and Pasig. }\end{array}$ \\
\hline No.3 & 24.3 & $\begin{array}{l}\text { Along Highway 54 (C-4): half a circle route about } \\
\text { 12 km from Manila downtown. }\end{array}$ \\
\hline No.4 & 30.1 & $\begin{array}{l}\text { From Marikina to Zapote via Cubao, Manila } \\
\text { downtown and the Manila Bay area. }\end{array}$ \\
\hline No.5 & 17.6 & $\begin{array}{l}\text { From Meycauayan to Manila downtown running } \\
\text { between Line No. 2 and PNR. }\end{array}$ \\
\hline
\end{tabular}

Table 4. Description of each light rail transit line in MMETROPLAN [15]

\begin{tabular}{|c|c|c|}
\hline Direction & $\begin{array}{c}\text { Length } \\
(\mathbf{k m})\end{array}$ & Description \\
\hline One-way & 13.84 & Rizal - Taft \\
\hline Round trip & 23.5 & Quezon (Ellipse) - Central - Quezon (Ellipse) \\
\hline Round trip & 14.4 & Quezon (Roosevelt) - Central - Quezon (Roosevelt) \\
\hline One-way & 11.6 & Shaw - Taft \\
\hline One-way & 15.0 & Shaw - Rizal \\
\hline
\end{tabular}

Table 5. Description of each railway line in MMUTIS [16]

\begin{tabular}{|c|l|}
\hline Proposed & \multicolumn{1}{c|}{ Description } \\
\hline Line 1 Extension & $\begin{array}{l}\text { The line will extend to Dasmarinas, Cavite in the south (30 } \\
\text { km elevated). }\end{array}$ \\
\hline Line 2 Extension & $\begin{array}{l}\text { The line will extend to Antipolo in the east (12 km } \\
\text { elevated) and to the west across Line 1 to the Port Area } \\
\text { from where the line passes along Roxas Boulevard and } \\
\text { Buendia to link Makati and Fort Bonifacio (17 km } \\
\text { underground). Then the line will further lead to } \\
\text { Binangonan in the east (20 km elevated/at-grade). }\end{array}$ \\
\hline Line 3 Extension & $\begin{array}{l}\text { The line will extend to Navotas and Obando (16 km } \\
\text { elevated) in the north across Line 1 and PNR. The line in } \\
\text { the south will extend to the reclamation area across Line 1 } \\
\text { and further extend to Kawit (15 km elevated/at-grade) in } \\
\text { the south. }\end{array}$ \\
\hline Line 4 & $\begin{array}{l}\text { The line will extend to San Mateo in the north via a branch } \\
\text { line. In the city center, instead of terminating on Recto } \\
\text { Avenue, it can take over the extension portion of Line 2. }\end{array}$ \\
\hline North Rail and & $\begin{array}{l}\text { A suburban commuter service will be provided between } \\
\text { Malolos and Caloocan (30 km at-grade). From there, the } \\
\text { line links Fort Bonifacio (20 km underground) and extends } \\
\text { to General Trias in the south (25 km } \\
\text { underground/elevated/at-grade). }\end{array}$ \\
\hline MCX and Extension & $\begin{array}{l}\text { A suburban commuter service will link Calamba with } \\
\text { Alabang (28 km at-grade) from where the line will be } \\
\text { elevated up to Paco (42 km). The line will then proceed } \\
\text { toward the north across EDSA (11 km underground) and } \\
\text { further extend northward to San Jose del Monte (18 km } \\
\text { elevated). }\end{array}$ \\
\hline
\end{tabular}




\begin{tabular}{|c|l|}
\hline ATTRIBUTE & DESCRIPTION \\
\hline From & The starting node of the link \\
\hline To & The ending node of the link \\
\hline Length & Measurement of the link \\
\hline Modes & The mode of transport that can pass through a given link \\
\hline Type & Category of the link specified \\
\hline Lanes & Number of lanes on the link \\
\hline VDF & Volume-delay function \\
\hline Time & Average time it takes for the vehicles to enter and exit from the link \\
\hline Speed & Average speed on the link \\
\hline AutoVol & Volume of private vehicles \\
\hline AddIVol & Volume of public vehicles \\
\hline TotVol & Sum of private and public vehicles \\
\hline VDT & Vehicle-distance-traveled \\
\hline VHT & Vehicle-hour-traveled \\
\hline
\end{tabular}

Table 7. Travel time cost and savings per transport plan

\begin{tabular}{|c|c|c|c|c|}
\hline \multirow{2}{*}{$\begin{array}{l}\text { TRANSPORT } \\
\text { PLAN }\end{array}$} & \multicolumn{3}{|c|}{ TRAVEL TIME COST (PHP/year) } & \multirow{2}{*}{$\begin{array}{l}\text { SAVINGS } \\
\text { (PHP/year) }\end{array}$} \\
\hline & Private & Public & TOTAL & \\
\hline PRESENT & $4,866,868,767,667.62$ & $50,211,594,531.84$ & $4,917,080,362,199.46$ & $\mathrm{n} / \mathrm{a}$ \\
\hline UTSMMA & $3,017,058,455,502.57$ & $36,825,631,952.64$ & $3,053,884,087,455.21$ & $1,863,196,274,744.25$ \\
\hline MMETROPLAN & $2,963,077,597,765.23$ & $36,876,008,820.48$ & $2,999,953,606,585.71$ & $1,917,126,755,613.75$ \\
\hline MMUTIS & $2,238,628,074,078.49$ & $28,811,547,354.24$ & $2,267,439,621,432.73$ & $2,649,640,740,766.73$ \\
\hline
\end{tabular}

Table 8. Vehicle operating cost and savings per transport plan

\begin{tabular}{|c|c|c|c|r|}
\hline \multirow{2}{*}{$\begin{array}{c}\text { TRANSPORT } \\
\text { PLAN }\end{array}$} & \multicolumn{2}{|c|}{ VEHICLE OPERATING COST (PHP/year) } & \multirow{2}{*}{$\begin{array}{c}\text { SAVINGS } \\
\text { (PHP/year) }\end{array}$} \\
\cline { 2 - 4 } & Private & Public & TOTAL & n/a \\
\hline PRESENT & $708,647,483,081.52$ & $21,899,990,188.80$ & $730,547,473,270.32$ & $31,806,701,800.32$ \\
\hline UTSMMA & $676,843,643,593.68$ & $21,897,127,876.32$ & $698,740,771,470.00$ & $31,807,143,041.52$ \\
\hline MMETROPLAN & $676,843,202,352.48$ & $21,897,127,876.32$ & $698,740,330,228.80$ & $32,131,696,827.04$ \\
\hline MMUTIS & $647,978,721,174.00$ & $21,437,055,269.28$ & $669,415,776,443.28$ & 61,130 \\
\hline
\end{tabular}

Table 9. Traffic safety benefits per transport plan of private vehicles

\begin{tabular}{|c|r|c|r|}
\hline \multirow{2}{*}{$\begin{array}{c}\text { TRANSPORT } \\
\text { PLAN }\end{array}$} & \multicolumn{2}{|c|}{ TRAFFIC SAFETY COST (/year) } & \multirow{2}{*}{$\begin{array}{c}\text { SAVINGS } \\
\text { (PHP/year) }\end{array}$} \\
\cline { 2 - 3 } & Private (USD, 1994) & $\begin{array}{c}\text { TOTAL (PHP, } \\
\text { 2014) }\end{array}$ & \\
\hline PRESENT & $7,234,028,827.29$ & $320,568,753,452.64$ & $\mathrm{n} / \mathrm{a}$ \\
\hline UTSMMA & $6,909,368,263.10$ & $306,181,745,210.84$ & $14,387,008,241.80$ \\
\hline MMETROPLAN & $6,909,363,758.81$ & $306,181,545,607.87$ & $14,387,207,844.77$ \\
\hline MMUTIS & $6,614,708,808.48$ & $293,124,206,138.88$ & $27,444,547,313.76$ \\
\hline
\end{tabular}

Table 10. Emissions of private vehicles per transport plan

\begin{tabular}{|c|c|c|c|}
\hline \multirow{2}{*}{$\begin{array}{c}\text { TRANSPORT } \\
\text { PLAN }\end{array}$} & NO $_{\mathbf{x}}$ & CO & CO $_{\mathbf{2}}$ \\
\cline { 2 - 4 } & $97,866,306,387.31$ & $743,385,358,352.47$ & $18,889,356,860,764.70$ \\
\hline PRESENT & $93,039,950,268.60$ & $661,307,864,936.58$ & $16,861,193,601,118.30$ \\
\hline UTSMMA & $93,079,853,165.00$ & $661,650,149,938.02$ & $16,853,899,686,588.10$ \\
\hline MMETROPLAN & $89,099,773,781.65$ & $621,197,036,657.54$ & $15,743,355,963,139.10$ \\
\hline MMUTIS & \multicolumn{3}{|c|}{ EMISSIONS (g/year) } \\
\hline
\end{tabular}

Table 11. Emission costs of private vehicles per transport plan in foreign currencies

\begin{tabular}{|c|r|r|r|}
\hline \multirow{2}{*}{$\begin{array}{c}\text { TRANSPORT } \\
\text { PLAN }\end{array}$} & \multicolumn{3}{|c|}{ EMISSION COST (/year) } \\
\cline { 2 - 4 } & NO $_{\mathbf{x}}(\mathbf{U S D}, \mathbf{2 0 0 2})$ & CO (EUR, 1998) & CO $_{\mathbf{2}}$ (EUR, 1998) \\
\hline PRESENT & $2,530,822.68$ & $112,994,574.47$ & $793,352,988.15$ \\
\hline UTSMMA & $2,406,013.11$ & $100,518,795.47$ & $708,170,131.25$ \\
\hline MMETROPLAN & $2,407,045.00$ & $100,570,822.79$ & $707,863,786.84$ \\
\hline MMUTIS & $2,304,120.15$ & $94,421,949.57$ & $661,220,950.45$ \\
\hline
\end{tabular}

Table 12. Environmental benefits of private vehicles per transport plan 


\begin{tabular}{|c|c|c|c|c|c|}
\hline \multirow{2}{*}{$\begin{array}{l}\text { TRANSPORT } \\
\text { PLAN }\end{array}$} & \multicolumn{4}{|c|}{ EMISSION COST (PHP/year) } & \multirow{2}{*}{$\begin{array}{l}\text { SAVINGS } \\
\text { (PHP/year) }\end{array}$} \\
\hline & $\mathrm{NO}_{\mathrm{x}}$ & CO & $\mathrm{CO}_{2}$ & TOTAL & \\
\hline PRESENT & $112,150,876.38$ & $6,653,572,523.07$ & $46,715,797,354.35$ & $53,481,520,753.80$ & $\mathrm{n} / \mathrm{a}$ \\
\hline UTSMMA & $106,620,065.13$ & $5,918,948,752.48$ & $41,699,890,008.35$ & $47,725,458,825.95$ & $5,756,061,927.84$ \\
\hline MMETROPLAN & $106,665,792.26$ & $5,922,012,329.20$ & $41,681,851,224.09$ & $47,710,529,345.55$ & $5,770,991,408.25$ \\
\hline MMUTIS & $102,104,780.33$ & $5,559,942,078.59$ & $38,935,334,446.41$ & $44,597,381,305.33$ & $8,884,139,448.47$ \\
\hline
\end{tabular}

Table 13. Co-benefits in UTSMMA

\begin{tabular}{|c|r|r|r|}
\hline CO-BENEFIT & \multicolumn{1}{|c|}{ Without Project } & \multicolumn{1}{c|}{ With Project } & \multicolumn{1}{c|}{ SAVINGS } \\
\hline Travel Time Cost (PHP/year) & $4,917,080,362,199.46$ & $3,053,884,087,455.21$ & $1,863,196,274,744.25$ \\
\hline Vehicle Operating Cost (PHP/year) & $730,547,473,270.32$ & $698,740,771,470.00$ & $31,806,701,800.32$ \\
\hline $\begin{array}{c}\text { Traffic Safety Cost of private } \\
\text { (PHP/year) }\end{array}$ & $320,568,753,452.64$ & $306,181,745,210.84$ & $14,387,008,241.80$ \\
\hline $\mathrm{NO}_{\mathrm{x}}$ of private (PHP/year) & $112,150,876.38$ & $106,620,065.13$ & $5,530,811.25$ \\
\hline $\mathrm{CO}$ of private (PHP/year) & $6,653,572,523.07$ & $5,918,948,752.48$ & $734,623,770.59$ \\
\hline $\mathrm{CO}_{2}$ of private (PHP/year) & $46,715,797,354.35$ & $41,699,890,008.35$ & $5,015,907,346.00$ \\
\hline TOTAL (PHP/year) & & & $\mathbf{1 , 9 1 5 , 1 4 6 , 0 4 6 , 7 1 4 . 2 1}$ \\
\hline
\end{tabular}

Table 14. Co-benefits in MMETROPLAN

\begin{tabular}{|c|r|r|r|}
\hline CO-BENEFIT & \multicolumn{1}{|c|}{ Without Project } & \multicolumn{1}{c|}{ With Project } & \multicolumn{1}{c|}{ SAVINGS } \\
\hline Travel Time Cost (PHP/year) & $4,917,080,362,199.46$ & $2,999,953,606,585.71$ & $1,917,126,755,613.75$ \\
\hline Vehicle Operating Cost (PHP/year) & $730,547,473,270.32$ & $698,740,330,228.80$ & $31,807,143,041.52$ \\
\hline $\begin{array}{c}\text { Traffic Safety Cost of private } \\
\text { (PHP/year) }\end{array}$ & $320,568,753,452.64$ & $306,181,545,607.87$ & $14,387,207,844.77$ \\
\hline $\mathrm{NO}_{\mathrm{x}}$ of private (PHP/year) & $112,150,876.38$ & $106,665,792.26$ & $5,485,084.13$ \\
\hline $\mathrm{CO}_{\text {of private (PHP/year) }}$ & $6,653,572,523.07$ & $5,922,012,329.20$ & $731,560,193.87$ \\
\hline $\mathrm{CO}_{2}$ of private (PHP/year) & $46,715,797,354.35$ & $41,681,851,224.09$ & $5,033,946,130.26$ \\
\hline TOTAL (PHP/year) & & & $\mathbf{1 , 9 6 9 , 0 9 2 , 0 9 7 , 9 0 8 . 2 9}$ \\
\hline
\end{tabular}

Table 15. Co-benefits in MMUTIS

\begin{tabular}{|c|r|r|r|}
\hline CO-BENEFIT & \multicolumn{1}{|c|}{ Without Project } & \multicolumn{1}{c|}{ With Project } & \multicolumn{1}{c|}{ SAVINGS } \\
\hline Travel Time Cost (PHP/year) & $4,917,080,362,199.46$ & $2,267,439,621,432.73$ & $2,649,640,740,766.73$ \\
\hline Vehicle Operating Cost (PHP/year) & $730,547,473,270.32$ & $669,415,776,443.28$ & $61,131,696,827.04$ \\
\hline $\begin{array}{c}\text { Traffic Safety Cost of private } \\
\text { (PHP/year) }\end{array}$ & $320,568,753,452.64$ & $293,124,206,138.88$ & $27,444,547,313.76$ \\
\hline $\mathrm{NO}_{\mathrm{x}}$ of private (PHP/year) & $112,150,876.38$ & $102,104,780.33$ & $10,046,096.06$ \\
\hline $\mathrm{CO}$ of private (PHP/year) & $6,653,572,523.07$ & $5,559,942,078.59$ & $1,093,630,444.47$ \\
\hline $\mathrm{CO}_{2}$ of private (PHP/year) & $46,715,797,354.35$ & $38,935,334,446.41$ & $7,780,462,907.94$ \\
\hline TOTAL (PHP/year) & & & $\mathbf{2 , 7 4 7 , 1 0 1 , 1 2 4 , 3 5 6 . 0 0}$ \\
\hline
\end{tabular}

Tables 13 to 15 show the savings quantified for each rail transit plan. Based from the tables, MMUTIS incurred the highest value of co-benefits with PHP 2.75 Trillion / year while UTSMMA had the least amount with PHP 1.92 Trillion / year. Figure 5 shows the percentages of co-benefits derived for each transport plan. MMUTIS consistently dominated the value of cobenefits while UTSMMA had the least percentage of cobenefits.

The methodology and calculations presented are useful for estimating not just the direct transport or traffic benefits (i.e., travel time and vehicle operating costs savings) that can be derived from transport infrastructure development such as mass transit projects. These can adequately estimate indirect benefits (i.e., safety and environment) as well as shown in the previous sections.
These estimations allow for a much better and quantitative appreciation of scenarios for what could have been (i.e., past projects that should have been implemented), and what could be (i.e., present and future projects) the benefits of transportation infrastructure projects. The methodology is definitely applicable for the cases of other cities as well. And these should encourage both government and the private sector to work towards the realization of such infrastructure in order to improve, among others, the quality of life in our cities.

\section{ACKNOWLEDGMENT}

This work was funded by the UP System Emerging Inter-Disciplinary Research Program (OVPAA-EIDR06-008). 
[1] United Nations, "United Nations Framework Convention on Climate Change," 1992. [Online]. Available: http://unfccc.int/files/essential_background/convention/backgrou nd/application/pdf/convention_text_with_annexes_english_for_ posting.pdf. [Accessed 13 May 2017].

[2] United Nations, "United Nations Framework Convention on Climate Change," 1998. [Online]. Available: http://unfccc.int/resource/docs/convkp/kpeng.pdf. [Accessed 8 July 2017].

[3] United Nations, "United Nations Framework Convention on Climate Change," 2015. [Online]. Available: http://unfccc.int/files/essential_background/convention/applicati on/pdf/english_paris_agreement.pdf. [Accessed 8 July 2017].

[4] LEDS Global Partnership, "Transport Co-benefits Calculator," 2 October 2015.2 [Online]. Available: http://ledsgp.org/resource/transport-co-benefitscalculator/?loclang=en_gb. [Accessed 10 July 2017].

[5] Ministry of the Environment, Japan, "The Co-benefits Approach for GHG Emission Reduction Projects," Tokyo, 2009.

[6] United States Environmental Protection Agency, "The Integrated Environmental Strategies Handbook," US EPA, Washington, DC, 2004.

[7] Institute for Global Environmental Strategies, "Mainstreaming Transport Co-benefits Approach: A Guide to Evaluating Transport Projects,” IGES, Japan, 2011.

[8] C. Doll and H. Farzaneh, "The Co-benefits Evaluation Tool for the Urban Transport Sector," UNU-IAS, Yokohama, 2014.

[9] C. K. Castillo, D. C. Sanqui, M. Ajero and C. Huizenga, "The Co-Benefits of Responding to Climate Change: Status in Asia," 2007.
[10] Victoria Transport Policy Institute, "Transportation Cost and Benefit Analysis II - Travel Time Costs," in Transportation Cost and Benefit Analysis: Techniques, Estimates and Implications, 2017, pp. 5.2-1-5.2-26.

[11] European Commission, "ExternE Project," 1998

[12] J. R. F. Regidor, D. S. Aloc, A. M. Fillone and K. J. C. Lucas, "What if Metro Manila Developed a Comprehensive Rail Transit Network?," in Eastern Asia Society for Transportation Studies Conference, Vietnam, 2017.

[13] A. M. Fillone, "Evaluating Proposed Transportation Infrastructure Projects in Metro Manila Using the Transport Cobenefit Analysis," Journal of the Eastern Asia Society for Transportation Studies, vol. 11, pp. 189-208, 2015.

[14] T. R. Miller, J. B. Douglass and N. M. Pindus, "Railroad injury: Causes, costs, and comparisons with other transport modes," Journal of Safety Research, vol. 25, no. 4, pp. 183-195, 1994.

[15] O. Toshiyumi, et al., "Measurement of the Effects of Environmentally Friendly Commodities Using Social Environmental Economics and Policy Studies," 2002.

[16] Overseas Technical Cooperation Agency, Urban Transport Study in Manila Metropolitan Area, 1973.

[17] Freeman Fox and Associates, MMETROPLAN Metro Manila Transport, Land Use and Development Planning Project Final Report: Main Volume, Hongkong, 1977.

[18] Japan International Cooperation Agency, Metro Manila Urban Transportation Integration Study, 1999.

[19] Japan International Cooperation Agency, Roadmap for Transport Infrastructure Development for Metro Manila and its Surrounding Areas (Region III \& Region IV-A): Final Report: Technical Report No.2 Transport Demand Analyis, 2014. 